\title{
Positive education: Learning and teaching for wellbeing and academic mastery
}

\author{
Mathew White · Margaret L. Kern
}

\begin{abstract}
Over the past decade, positive education has emerged as a rapidly growing arm of positive psychology that has attracted both interest and critique. Through a case study, we show that positive education can positively impact students, teachers, and others within the educational community, but success is not immediate nor imminent. We suggest that successful positive education programs blend evidence-based learning from the science of positive psychology, best practices in learning and teaching, whole school strategy, and evaluation, and consider pedagogy, philosophical assumptions, and the school's culture. Positive education must be studied, applied, and managed responsibly, as there is also potential that attempts are ineffective or do harm. Finally, we consider implications for training, teaching, and professional practice. Positive education has made significant progress, but future research and application will benefit from a unified theoretical framework that adequately incorporates educational knowledge and pedagogical practice.
\end{abstract}

Keywords: positive education, positive psychology, wellbeing science, professional practice, culture change, critical perspective

\section{Introduction}

Over the past two decades, there has been exponential growth in the research and practice of positive psychology across a range of fields, including organizations, healthcare, and public policy, following the publication of Seligman and Csikszentmihalyi's (2000) introduction to the field. The application to education - positive education - has attracted considerable attention from researchers, practitioners, and policymakers. For example, a growing number of schools have adopted a scientific approach to wellbeing (McCallum \& Price, 2010; McCallum \& Price, 2012; McCallum \& Price, 2015; McCallum \& Price, 2017; Rusk \& Waters, 2013; Rusk \& Waters 2015; Seligman, 2011; Seligman, Ernst, Gillham, Reivich, \& Linkins, 2009; Slemp et al., 2017; Waters, 2011; White \& Murray, 2015; White et al., 2017;). Training programs are available around the world. Research, application, and advocacy is further supported through national and international organizations such as the International Positive Psychology Association's education division (www.ippanetwork.org/divisions/education), the Positive Education Schools Association (www.pesa.edu.au) and the International Positive Education Network (www.ipen-network.com).

While this growth is promising, it has also been met with various critiques, both within academia (e.g., Ciarrochi, Atkins, Hayes, Sahdra \& Parker, 2016; Kristjánsson, 2012; Suissa, 2008; White, 2016) and beyond. Rhetoric can run ahead of the science, and the growing number of available programs, while providing important resources to schools, can also cause 
confusion as to which ones should or should not be followed. From our experience, as schools juggle the many demands of curriculum, time, and resources, positive education is often conceived as a specific program which requires school leaders to choose between education for academic success or for wellbeing.

As teachers, schools, and educational systems consider the ideas of positive education, it is essential to recognize the role of pedagogical practice. For example, critical interrogation is needed around: the cacophony of unaccredited wellbeing trainers and self-styled wellbeing centres, returns on time and investment, the choice of educational programs within the schools, and understanding the relationship between wellbeing and academic mastery. Importantly, activity is not the same as impact. When done well, positive education has the potential to profoundly shape and impact the lives of future generations. But if pedagogy is ignored, then positive education will become yet another failed change initiative. We argue that the time has come for the discourse on the pedagogy of positive education to become more sophisticated, with emphasis on educating the whole person - learning and teaching for wellbeing and academic mastery.

In this article, we first briefly revisit what positive education is and why it matters. We present a case study showing the impact that it can have. We illustrate that a positive education program can be successful, but also bring numerous challenges. Finally, we consider implications for training, teaching, and practice.

\section{Positive education}

Positive education has been defined in various ways, but most definitions stem from the paper by Seligman et al. (2009) which defined it as "education for both traditional skills and for happiness" (p. 293). The International Positive Education Network (IPEN, www.ipennetwork.com) suggests that positive education is a double helix with intertwined strands of equal importance - academics and character or wellbeing. Based on a review of 150 journal articles, chapters, and books published over the past nine years, White and Murray (2015) argued that positive education is an umbrella term that is used to describe empirically validated interventions and programs from positive psychology that have an impact on student wellbeing.

At its core, positive education builds on the science of positive psychology, a perspective and approach that has existed across millennia, and represents philosophies, theories, research, and applications that are preventative and strengths based in nature, and aim to understand and cultivate optimal human function. What has taken positive psychology from the philosophical and theological domains to an established field is its emphasis on incorporating scientific approaches (Ambler, Anstey, McCall, \& White, 2017; Charry \& Kostis, 2017; Kristjánsson, 2013; White et al., 2017). Indeed, if positive education is to differentiate itself from other areas, it is essential that this empiricism is at the heart of research and practice, demonstrating substantial impact on student development.

However, alongside empiricism, a clear valuing of the practical application by educators is needed. While definitions of positive education are appealing at a theoretical level, they leave little guidance for teacher practice. What are skills for happiness? What does it mean to have wellbeing and character intertwined with academics? If the scientific approaches of positive education are to be integrated, then complete integration of data with decision-making and professional practice is needed (Hattie, 2016). 


\section{Why positive education matters}

Educators face numerous competing challenges, including: falling literacy and numeracy rates, absenteeism, school engagement and retention. Why should schools make room for positive education? Based on relevant literature over the past 10 years (e.g., Boniwell, 2012; Brunzell et al, 2015; Brunzell, Stokes \& Waters, 2016a; Brunzell, Stokes \& Waters, 2016b; Brunzell, Stokes \& Waters, 2018; David, Boniwell, \& Ayers, 2013; Furlong, Gilman, \& Huebner, 2014; Gilman, Huebner, \& Furlong, 2008; Noble, Wyatt, McGrath, Roffey \& Rowling, 2008; Roffey, 2012, 2016; Slemp et al., 2017; Waters, 2015; Waters, 2017; Waters et al., 2017; White, 2010, 2013; White et al., 2017), we suggest that there are six reasons for embedding positive education within educational systems: philosophical, psychological, social, cognitive, economic, and cultural.

\subsection{Philosophical}

Wellbeing and virtue ethics have a rich philosophical history, grounded primarily in the Aristotelian vision of eudemonia (Arthur, Kristjánsson, Harrison, Sanderse, \& Wright, 2016; Carr, Arthur, \& Kristjánsson, 2017; Kristjánsson, 2007, 2015). As is commonly noted throughout the wellbeing literature, in the Aristotelian perspective, wellbeing is understood as an outcome of a pathway towards a flourishing life. However, an often-overlooked element of Aristotle's writings is the pursuit of wellbeing not only for its own sake, but as a citizen of the "polis" or city-state of classical Greece (Nicomachean ethics, T. Irwin, Trans, 1985). Hence, the inspiration of what it means to be a good citizen, live well within a community, develop good character and be free was strongly associated with the formation of the early city-states of ancient Greece. Aristotle's understanding of citizenship has long influenced Western democracy throughout the world, with the assumption that if we are to be fully human, we must be active citizens helping to create a flourishing state. Thus, a focus on wellbeing is not only about how individual students feel, but also, as suggested by the positive youth development literature and character education (e.g., Kern, Park, Peterson, \& Romer, 2017; White \& Murray, 2015), their journey towards becoming contributing members of society.

\subsection{Psychological}

High rates of mental illness and suicide in developed countries globally have raised awareness of the need to better understand and support student mental health (IPEN, 2017). The World Health Organization (2017) indicates that mental illness is the greatest cause of disability for young people worldwide. By age 25, one in four young people will have experienced at least one occurrence of severe mental illness (Slade, Johnston, Oakley Browne, Andrews, \& Whiteford, 2009; World Health Organization, 2017). Suicide and accidents are the main causes of death for young people age 16 to 25. The Australian Institute of Health and Welfare (2011) reports that in an average Year 12 classroom, one young person has attempted suicide, and an unknown number of others have thought about it. Today's five-year-old will emerge and graduate in 2030 -- the same year that the World Health Organization predicts that depression will create the highest level of disability of any mental or physical disorder (World Health Organization, 2001). If such trends continue, many of the brightest and most innovative youth will not make it to adulthood or will enter adulthood crippled by chronic disorder.

The earlier that a young person experiences mental illness, the greater the risk of extended disability, repeated incidences, and numerous negative life outcomes, including dropping out of school, unemployment, delinquency, poor social relationships, and physical and mental health problems (Kessler \& Bromet, 2013). Keyes (2014) argued, “It's often said that the youth is 
the nation's future. If this is true, then there is too much mental illness to look forward to in the future." Schools act as a first line of defence against mental illness, with a capacity to prevent or lessen the impact of mental illness (Kern, Waters, Adler, \& White, 2015; White \& Kern, 2017).

\subsection{Social}

Human beings have a deep-seated need to relate with others and feel a sense of belonging (e.g., Allen \& Kern, 2017; Baumeister \& Leary, 1995; Deci \& Ryan, 2008; McClelland, 1987; Vallerand, 1997). Systematic reviews identify that a sense of belonging strongly impacts academic, psychological, social, and behavioral outcomes (Allen \& Kern, 2017, Allen, Kern, VellaBrodrick, Hattie, \& Waters, 2018). The presence or absence of and the quality of social relationships impact psychological and physical health, and length of life (Tay, Tan, Diener, \& Gonzalez, 2012; Taylor, 2011). Relationships are also dynamic. They are influenced by the interrelationships of two or more individuals, including the qualities of each person, their commitment to the relationship, their communication styles, and each person's needs, goals, standards, and expectations (Finkel, Simpson, \& Eastwick, 2017). Any applications of happiness need to recognize how important social connection and prosocial behaviors are for wellbeing (Helliwell \& Aknin, 2018).

Childhood and adolescence are primary periods when social connections beyond the family develop (Allen \& Kern, 2017). Peers and friendships are pivotal to how the individual thinks and feels about him or herself (Quinn \& Oldmeadow, 2012). And teachers have considerable influence on the academic, social, and emotional outcomes of students under their care, for better or for worse (e.g., Allen \& Kern, 2017; Anderman, 2002; Crouch, Keys, \& McMahon, 2014; Hattie, 2009; Wang \& Eccles, 2012).

Over the past few decades, the socializing role of schools has become increasingly important, as modern society has become increasingly mobile, traditional family structures have shifted, and technology is changing communication patterns (Hayes, Weston, Qu \& Gray, 2010). Further, social skills form a core part of the most valued characteristics of the $21^{\text {st-century }}$ workplace (Foundation for Young Australians, 2016, 2017; Hanover Research, 2011). Social and emotional learning programs that specifically target social skills can help young people understand and manage their emotions, develop positive relationships with others, make responsible decisions, and possibly perform better academically (Durlak, Weissberg, Dymnicki, Taylor, \& Schellinger, 2011).

\subsection{Cognitive}

One of the biggest challenges that schools are facing is how to engage students in their learning. School engagement has been defined in a myriad of ways, but generally includes behavioral, psychological, and cognitive aspects (Appleton, Christenson, \& Furlong, 2008). It includes feeling a part of the school, being interested in learning, paying attention, and participating in school activities, versus being bored, disinterested in learning, and uninvolved at school. Disengaged students are at increased risk for skipping class, dropping out, and a variety of anti-social behaviors (e.g., Cook, Dodge, Gifford, \& Schulting, 2017).

In a review of studies considering the impact of positive psychology interventions in school, Waters (2011) found that school engagement and retention can be enhanced through positive psychology interventions. For example, mindfulness interventions have been shown to increase attention, memory performance, and problem-solving in young adults, (Creswall, 2017), and school-based interventions have demonstrated improvements in cognitive 
performance, stress, resilience, and emotional problems (Zenner, Herrnleben-Kurz, \& Walach, 2014).

\subsection{Economic}

The cost on national economies each year for mental illnesses is substantial (World Health Organization, 2017). An Australian report estimated that the cost of Australia's mental illness is A \$3.27 billion per year (Degney et al., 2012). The annual cost of suicide for Australia equates to A $\$ 17.5$ billion. Beyond direct costs, there is also the number of productive life years lost due to disability or early mortality. These significant figures illustrate the cost and the impact of youth mental health on national economies. Preventative approaches often cost more up front but create substantial savings in the long term. If we can prevent even some youth from mental illness and save lives, then it means substantial economic benefits in the future.

\subsection{Cultural}

Culture has been defined as the specific practices of a group or a particular orientation (e.g., individualism versus collectivism) for interpreting and making sense of experiences and situations (Oyserman, 2017). Culture is both stable and dynamic, as norms, values, traditions, and more are passed down through generations and evolve. Through globalization, different cultures are increasingly being brought together, at times peaceably, at other times violently.

Schools have their own cultures, implicitly and explicitly establishing and reinforcing norms and expectations, and creating a lens for young people to understand and experience their world (Hviid \& Villadsen, 2014). The design of the school, classroom environment, how teachers treat students, and the language used on campus impact how students think about themselves and how they interpret and make sense of their world (Allen \& Kern, 2017). Hattie (2016) identified the need to make schools an inviting learning environment as one of the core factors needed to reboot the Australian education system. Culture either naturally arises or is purposefully created (White \& Murray, 2015). Positive education aims to explicitly and implicitly shift school cultures in ways that empower students to develop a positive lens for experiencing the world (White et al., 2017).

\section{Positive education in practice}

Positive education can involve explicit teachings and lessons (i.e., a taught curriculum), and/or implicitly through aspects of the school culture (i.e., a caught curriculum).

The taught curriculum involves the purposeful application of positive psychology within scheduled class time. This may entail a clear scope and sequence that is developmentally appropriate, lessons which are culturally sensitive, a dedicated team of teachers who can respond and adapt to student feedback, and a focus on long-term goals in the delivery of positive education lessons. This approach primarily takes the ideas and findings from positive psychology and blends them with practical curricula. There are a growing number of empirically informed and scientifically structured wellbeing programs that develop scope and sequence of skills to young people (e.g., Boniwell \& Ryan, 2012; McGrath \& Noble, 2011, Seligman et al., 2009; see Slemp et al., 2017 for a review).

The caught curriculum reflects the overall culture, feeling, or tone of a school (White, 2016). It appears in the language used, how staff and students interact with one another, and implicit norms of the school. A benefit of the caught curriculum is that it interferes less with already established and crowded curricula (White, 2014, 2016; White \& Murray, 2015; White \& Waters, 
2015a, 2015b). Decision makers are already challenged to manage overcrowded curricula, with primary focus on numeracy and literacy. Wellbeing is seen either as a marginalized topic or as a marketing tool, along with co-curricular "extras" for schools to differentiate themselves from competitors (Hattie, 2016). Incorporating positive education into the culture without specific lessons offers the possibility of emphasizing wellbeing without taking time away from learning. However, relegating positive education to the caught curriculum also risks further marginalizing wellbeing, as it is seen as an added extra, rather than being a core part of education.

It is essential that there is not only a clear culture of wellbeing promoted within a school but also clear support for wellbeing within the classrooms themselves. While there are benefits and disadvantages to both approaches, we believe that the greatest benefit will arise from the combination of caught and taught approaches. Still, studies are needed to determine the extent to which the taught versus the caught curriculum should be emphasized, and the extent to which this varies based on the existing needs and culture of the school.

\section{Evidence for positive education: A case study}

A growing number of schools around the world show early signs of having successfully implemented positive education. A review of schools and programs is beyond our scope here; instead, we focus on evidence and lessons learned from one school - St. Peter's College Adelaide, Australia.

St. Peter's College is an all boys' K-12 school in South Australia. Founded in 1847, it is one of the leading independent schools of Australia. St. Peter's College has graduated three Nobel Laureates, ten Australian Premiers and 42 Rhodes Scholars. It has over 1,448 students, all boys, from 3-year-olds to 18-year-olds. It has a staff of 250 people, and its school's vision is "to be a world-class school where all boys flourish" (St. Peter's College, 2015).

Our focus here is not on what the school has done, which has already been well documented (Alford \& White, 2015; Kern, Waters, White, \& Adler, 2014; Kern, Waters, Adler, \& White, 2015; McCall, Waters, \& White, 2015; Waters, White, Wang, \& Murray, 2015; White \& Murray, 2015; White, Vrodos, \& McNeil, 2015; White \& Waters, 2015a, 2015b; Waters, White, \& Murray, 2012), but rather, on lessons learned through its challenges and successes. That is, our focus is on the impact of the introduction of wellbeing programs, rather than the activity of these programs.

\subsection{Incorporating positive education at St. Peter's College - Adelaide}

A school's strategic plan sets measurable outcomes that determine the whole school structure, provide evidence for the success of efforts, and are reported to the school community. At St. Peter's College, wellbeing was added to the school's strategic plan in 2011. The plan was further revised in 2016, resulting in four primary objectives:

1) To be a safe, inclusive, supportive, and respectful learning and working environment for all members of the school community.

2) To teach, build, and embed personal and competencies for wellbeing across the school.

3) To ensure all staff, regardless of whether they are teaching or support staff, embrace student wellbeing as essential to their role and responsibilities.

4) To advance St. Peter's College as an international center of excellence for best practice and wellbeing by leading educational debate and sharing learning with others. 
Since 2011, staff have received training in resilience from the staff at the University of Pennsylvania's Center for Positive Psychology, 12 staff members have graduated from the University of Melbourne's Graduate School of Education's Professional Certificate in Positive Education, and one has graduated from the Master of Applied Positive Psychology program at the University of Melbourne.

Aiming for a whole school approach to wellbeing, the focus on wellbeing has been gradually incorporated throughout the school's ecosystem. The school has adopted very clear leadership and vision around wellbeing, in alignment with governance, strategy, and management. Staff receive training and opportunities to develop their wellbeing. All students have now received multiple scientifically-informed programs, (i.e., the taught curriculum). Wellbeing has been incorporated into sports, leadership, and co-curricular activities (i.e., the caught curriculum). The school is also committed to sharing knowledge with parents, the local community, educators, academics, and policy makers.

\subsection{The impact of positive education on St. Peter's College - Adelaide}

Wellbeing assessment and program evaluation have occurred since 2011. The assessments suggest that students have benefitted from positive education, with at-risk students benefitting the most. Wellbeing data has informed programming and has helped school teams to discuss the links between strength of character and academic mastery. The data provide early indications that the culture of the school is shifting.

Many students at the school perceived positive education as a beneficial addition to their schooling experience. We asked students a number of subjective questions about their experiences at school, including how their knowledge and understanding of the significance of wellbeing resilience has changed, and their understanding of the significance of their friends' wellbeing and resilience. As seen in Table 1 (below), in both 2014 and 2016, the majority of junior school students had a good understanding of the significance of the wellbeing and resilience for themselves and their friends, with over $90 \%$ reporting some understanding. By 2016, they perceived that positive education helped them to be a better student and to have better relationships with family and friends.

Senior school students perceived wellbeing and resilience as less significant and saw fewer links with positive education. Still, over a quarter believed that positive education helped them in their academic, social, and family roles. One student noted: "Although it may not have helped me personally I think that if people concentrated in class more of [sic] what is going on, they could benefit from it."

Second, students at risk for lower academic, behavioral, and psychosocial outcomes have seemingly benefited from the focus on wellbeing. Using wellbeing and academic data collected in 2011 and 2014, we compared high-performing students (i.e., A to A+ range) with lowerperforming students ( $\mathrm{B}$ and $\mathrm{C}$ range), based on average grades. High-performing students were generally satisfied overall with life, reported feeling engaged with school and connected with peers, and saw themselves as being gritty, determined to achieve their goals, and high in perseverance. In contrast, lower-performing students felt less engaged and connected with school. Notably, both the 2014 and 2016 surveys indicated that these lower-performing boys perceived that they benefitted and were learning more from the positive education programs than the high-performing students.

Third, the focus on wellbeing, combined with embedding wellbeing assessment, has helped inform programming and pastoral care. For example, in 2011, a merit system was introduced, which documents what students do well. These positive actions are communicated via an email 
generated to the student, the parents, and the student's mentor at the school. The school has seen an exponential rise in the number of merits received, as well as a steady decline in the number of behaviors and concerns from years 7 to 12 which have been reported by school staff.

Table 1. Student subjective perspectives of positive education, 2014 and 2016 reports

\begin{tabular}{|c|c|c|c|c|c|c|c|c|}
\hline \multirow{3}{*}{$\begin{array}{l}\text { To what extent } \\
\text { has positive } \\
\text { education helped } \\
\text { you... }\end{array}$} & \multicolumn{4}{|c|}{2014} & \multicolumn{4}{|c|}{2016} \\
\hline & \multicolumn{2}{|c|}{$\begin{array}{c}\text { Junior School } \\
N=209\end{array}$} & \multicolumn{2}{|c|}{$\begin{array}{c}\text { Senior School } \\
N=506\end{array}$} & \multicolumn{2}{|c|}{$\begin{array}{c}\text { Junior School } \\
\quad N=161\end{array}$} & \multicolumn{2}{|c|}{$\begin{array}{c}\text { Senior School } \\
\quad N=773\end{array}$} \\
\hline & Somewhat & $\begin{array}{l}\text { Very } \\
\text { Much }\end{array}$ & Somewhat & $\begin{array}{l}\text { Very } \\
\text { Much }\end{array}$ & Somewhat & $\begin{array}{l}\text { Very } \\
\text { Much }\end{array}$ & Somewhat & $\begin{array}{l}\text { Very } \\
\text { Much }\end{array}$ \\
\hline $\begin{array}{l}\text { Understand the } \\
\text { significance of } \\
\text { wellbeing and } \\
\text { resilience? }\end{array}$ & $95 \%$ & $64 \%$ & $79 \%$ & $46 \%$ & $93 \%$ & $71 \%$ & $80 \%$ & $44 \%$ \\
\hline $\begin{array}{l}\text { Understand the } \\
\text { significance of } \\
\text { your friends' } \\
\text { wellbeing and } \\
\text { resilience? }\end{array}$ & $93 \%$ & $62 \%$ & $83 \%$ & $46 \%$ & $95 \%$ & $75 \%$ & $83 \%$ & $51 \%$ \\
\hline $\begin{array}{l}\text { Understand the } \\
\text { significance of } \\
\text { your strengths? }\end{array}$ & $92 \%$ & $60 \%$ & $83 \%$ & $50 \%$ & $91 \%$ & $73 \%$ & $82 \%$ & $47 \%$ \\
\hline $\begin{array}{l}\text { Understand the } \\
\text { significance of } \\
\text { your friends' } \\
\text { strengths? }\end{array}$ & $93 \%$ & $63 \%$ & $81 \%$ & $44 \%$ & $90 \%$ & $75 \%$ & $83 \%$ & $49 \%$ \\
\hline $\begin{array}{l}\text { Become a better } \\
\text { student? }\end{array}$ & $78 \%$ & $48 \%$ & $50 \%$ & $21 \%$ & $87 \%$ & $57 \%$ & $58 \%$ & $26 \%$ \\
\hline $\begin{array}{l}\text { Have better } \\
\text { relationships with } \\
\text { your family? }\end{array}$ & $73 \%$ & $41 \%$ & $47 \%$ & $19 \%$ & $83 \%$ & $50 \%$ & $56 \%$ & $24 \%$ \\
\hline $\begin{array}{l}\text { Have better } \\
\text { relationships with } \\
\text { your friends? }\end{array}$ & $73 \%$ & $48 \%$ & $48 \%$ & $20 \%$ & $87 \%$ & $58 \%$ & $58 \%$ & $27 \%$ \\
\hline
\end{tabular}

Having the data on hand also stimulated conversations within school pastoral care teams, and between students and their mentors. Programming was determined in part by the needs identified at different year levels.

The data also made it clear that wellbeing and academic performance were not mutually exclusive. As shown in Figure 1 (below), students who demonstrated high levels of perseverance, growth mindset, grit, and school engagement also performed better academically and were rated more positively by their teachers regarding cooperation, effort, and organization, with correlations being stronger over time. This does not imply that wellbeing causes good academic performance, but rather suggests that positive education may be simultaneously beneficial to wellbeing and academic performance. Finally, there are early indications that the culture of the school has shifted. Students were much more likely to report mental health difficulties in 2016 than in 2011. One student aptly noted: "This school has 
changed significantly in the last 10-15 years due to this positive wellbeing program and it has created a more inclusive and richer culture at Saints."

Figure 1. Correlations between wellbeing and academic performance, 2012-2014

\begin{tabular}{|c|c|c|c|c|c|c|}
\hline & Engagement & Perseverance & Optimism & Connected & Happiness & $\begin{array}{c}\text { Overall } \\
\text { Wellbeing }\end{array}$ \\
\hline $\begin{array}{l}\text { Cooperation } \\
2012\end{array}$ & & ++ & & + & & + \\
\hline Effort 2012 & & + & & & & \\
\hline $\begin{array}{l}\text { Organization } \\
2012\end{array}$ & & + & & & & \\
\hline GPA 2012 & + & + & & & & \\
\hline $\begin{array}{l}\text { Cooperation } \\
2013\end{array}$ & + & ++ & + & ++ & & ++ \\
\hline Effort 2013 & + & ++ & & ++ & & ++ \\
\hline $\begin{array}{l}\text { Organization } \\
2013\end{array}$ & & ++ & + & ++ & & ++ \\
\hline GPA 2013 & ++ & ++ & & + & & ++ \\
\hline $\begin{array}{l}\text { Cooperation } \\
2014\end{array}$ & + & ++ & ++ & ++ & ++ & ++ \\
\hline Effort 2014 & & ++ & ++ & ++ & ++ & ++ \\
\hline $\begin{array}{l}\text { Organization } \\
2014\end{array}$ & + & ++ & ++ & ++ & ++ & ++ \\
\hline GPA 2014 & & ++ & & & & \\
\hline
\end{tabular}

$+=p<.05,++=p<.01$

\section{The challenge of applying positive psychology within education}

We suggested that philosophically, psychologically, socially, cognitively, economically, and culturally, a case can be made for positive education. Successes at schools such as St. Peter's College provide early evidence that positive education can be beneficial. A growing number of reports from other schools similarly point to the potentials for positive education (e.g., Adler, 2017; IPEN, 2017; Noble \& McGrath, 2015; Norrish, 2015; White et al., 2017). However, the question remains as to the extent to which these programs integrate positive psychology with education, rather than simply imposing the ideas of positive psychology on schools. Researchers in positive psychology have successfully developed a variety of interventions to help improve individual wellbeing, but applying simple interventions within the complexity of educational settings is a challenging task. Some of the common misconceptions about change within education are that it is linear, constructive, and always a good thing (White, 2016). The reality is that change is often messy and disorganized, with growth in unexpected areas, and numerous unintentional consequences (Kern, Siokou, Spong, \& Oades, 2017).

The rapid growth of positive psychology and its applications in different fields is clearly evident (Donaldson, Dollwet, \& Rao, 2015; Rusk \& Waters, 2013). However, we would suggest that decision-makers can learn from Elmore (1996) and his work on the impact of innovation and change within education, and the impact on professional practice for teachers. Elmore argued:

The closer an innovation gets to the core of schooling, the less likely it is that it will influence teaching and learning on a large scale. The corollary of this 
proposition, of course, is that innovations that are distant from the core will be more readily adopted on a large scale (p. 4).

Elmore's learnings on the professional practice and innovation within education systems are a timely reminder for the exceptional exponential growth of positive education. The movement seems to have struck a chord for many teachers and professional educators, which suggests that innovation for wellbeing within schools lies deeply at the heart of what it actually means to learn and to teach (Kristjánsson, 2012). Nevertheless, when Elmore's rationale is applied, it is likely that, as the ideas of positive education are scaled, the more challenging it will become to successfully implement those ideas.

To implement positive education successfully, there are numerous factors that schools must wrestle with and mitigate (White, 2016):

1) Financial implications of incorporating positive education into the taught and caught curriculum. Early investment is often needed, with the return on investment not apparent until years later.

2) Making the case for all stakeholders that wellbeing is not a marginal topic when compared with other areas such as numeracy and literacy.

3) The tendency for education systems to be able to consider either-or thinking (i.e., it is either wellbeing or academics rather than wellbeing and academics).

4) The growth of maverick providers in the field, where individuals are setting up questionable programs and questionable training products with varied or no evidence whatsoever of long-term impacts.

5) The over-reliance on "science," following the scientific method and a reductionist approach to research, and the under-reliance on philosophy and educational best practices.

6) Traditional forms of governance that take place within many school systems and schools that are primarily focused on negative or deficit-based thinking.

7) Rhetoric suggesting that positive education provides a silver bullet for the problems of education, which is disregarded when it indubitably is not.

8) Substantial socioeconomic and cultural challenges between and within schools.

Decision makers are continually challenged to maintain financial sustainability and demonstrate returns on financial investments. In many instances, they are looking at shortterm measures such as high stakes testing and overlooking the long-term strategies needed to support optimal development.

Positive education is further challenged by over-reaching claims, which can be criticized as simply rebranding education to gain a competitive edge (Hutchinson, 2017; Kenway, 2013). When positive education is proposed to solve a myriad of challenges within education itself, including illiteracy, disengagement, and even mental illness, then the program is bound for failure. Too often, the ideas and interventions of positive psychology sound as if they can be replicated immediately in other settings. Wellbeing takes place within schools, classrooms, staff rooms, and within parent bodies, which are all impacted by specific cultural settings. Based on our experience and understanding of both research and education, we suggest that if these different perspectives and stakeholders are ignored, then the introduction of wellbeing will be just another "fad," or a slick marketing campaign for a school to adopt to reinvent itself, which will fail to stick amidst the reality of the pressures and challenges within a school. 


\section{Implications for professional practice}

These challenges have several implications for professional training and teaching practice. With the development and exponential demand at the grassroots level within schools for wellbeingrelated learning, there is a need to upskill teachers, staff, and school leaders with not only understanding about and activities related to positive education, but also the reality of the challenges that exist. The rising rates of mental illness suggest that many teachers are now faced with not only being an educator, but also must deal with the psychosocial issues that students bring to the classroom. The implication is that pre-service teacher education and ongoing professional development for staff should equip educators with an accurate and timely understanding of what it means to manage both their own wellbeing and that of their students.

A growing number of taught programs, such as BounceBack! (McGrath \& Noble, 2011), the Penn Resilience Training (Brunwasser, Gillham \& Kim, 2009), Kids Matter (Department of Health, Australian Government, 2018), and Happy Classrooms (Centre for Education Innovation, 2015) have been developed, which is an encouraging sign. But as the number of programs increases, it can be confusing as to which program(s) should be chosen. It is important that schools consider the fit of the program to their needs, making modifications when appropriate, while carefully documenting changes made and their impact of the program. Clear attention should be paid to teacher practice, avoiding over-reliance on curriculum alone. While positive education can have benefits, it is not a silver bullet, and it is not a quick-fix solution. In addition, with the significant number of "maverick providers" (White, 2016), there is a need for some degree of caution, skepticism, and, potentially, regulation.

Professional leadership is responsible to make relevant decisions about how to operationalize wellbeing programs within a school, and how to select training opportunities that uphold scientific rigor. Care needs to be taken in how the change process is introduced and managed within the school. Leaders also need to take care of their wellbeing in order to adequately enable wellbeing in those they lead. In addition, school boards of directors need to be educated as to why wellbeing matters as an operational goal (White, 2014). We suggest that such bodies should hold schools accountable for supporting the wellbeing of all members of the educational community, and have the responsibility to support well-designed, evidencebased efforts within the school. The challenge of creating positive change should be acknowledged. While boards should require evidence for positive education efforts, this needs to be tempered by an acknowledgement that the greatest impacts of supporting positive education may not be seen for many years.

Finally, to move the field of positive education forward, we suggest that researchers and practitioners need to work closely together, considering how the concepts of positive psychology translate within the complexities of different school environments. This should be underpinned by robust measurement, which incorporates both quantitative and qualitative data to support program development and evaluation.

\section{Conclusion}

Positive education has considerable potential, but must be studied, applied, and managed in a responsible manner. When successful, a growing body of literature suggests that positive education programs do have a positive impact on the way that many students know and understand themselves, their peers, and their families. Evidence suggests that 
students who are at risk learn and benefit from positive education. Wellbeing data helps school teams conceptually link between wellbeing concepts and academic mastery, and can inform practice within the school. However, a unified theoretical framework of positive education is needed, which adequately brings together positive psychology with educational knowledge and pedagogical practice, acknowledges the challenges of change within the educational environment, and stresses the importance of evaluation. Only then can the field adequately put forward positive education as the heart of a new approach to pedagogy (White et al., 2017).

\section{Acknowledgments}

We dedicate this work to Jennifer H. White (1938-2018) and Ronald M. Kern (1945-2015).

\section{Authors}

Mathew Alan White

University of Adelaide

mathew.white@adelaide.edu

Margaret L. Kern

University of Melbourne

\section{Publishing Timeline}

Received 11 January 2017

Accepted 15 April 2018

Published 13 July 2018

\section{References}

Adler, A. (2017). Positive education: Educating for academic success and for a fulfilling life. Papeles Del Psicólogo, 38(1), 50-57.

Alford, Z., \& White, M. A. (2015). Positive school psychology. In M. A. White \& A. S. Murray (Eds.), Evidence-based approaches in positive education: Implementing a strategic framework for well-being in schools (pp. 93-110). Dordrecht, the Netherlands: Springer.

Allen, K. A., \& Kern, M. L. (2017). School belonging in adolescents: Theory, research, and practice. Singapore: Springer.

Allen, K., Kern, M. L., Vella-Brodrick, D., Hattie, J., \& Waters, L. (2018). What schools need to know about fostering school belonging: A meta-analysis. Educational Psychology Review, 30(1), 1-34. https://doi.org/10.1007/s10648-016-9389-8

Ambler, G., Anstey, A., McCall, T., \& White, M. (2017). Flourishing in faith: Theology and positive psychology. Eugene, OR: Cascade Books, Wipf and Stock.

Anderman, E. M. (2002). School effects on psychological outcomes during adolescence. Journal of Educational Psychology, 94, 795-809. https://doi.org/10.1037/0022-0663.94.4.795

Appleton, J. J., Christenson, S. L., \& Furlong, M. L. (2008). Student engagement with school: Critical conceptual and methodological issues of the construct. Psychology in the Schools, 45(5), 369-386. https://doi.org/10.1002/pits.20303

Arthur, J., Kristjánsson, K., Harrison, T., Sanderse, W., \& Wright, D. (2016). Teaching character and virtue in schools. London, England: Routledge.

Australian Institute of Health and Welfare. (2011). Young Australians: Their health and wellbeing 2011. (Cat. no. PHE 140). Canberra, Australia: Author. https://www.aihw.gov.au/reports/childrenyouth/young-australians-their-health-and-wellbeing-2011/contents/table-of-contents 
Baumeister, R. F., \& Leary, M. R. (1995). The need to belong: Desire for interpersonal attachments as a fundamental human motivation. Psychological Bulletin, 117(3), 497-529. https://doi.org/10.1037/0033$\underline{2909.117 .3 .497}$

Boniwell, I. (2012). Positive psychology in a nutshell: The science of happiness. Maidenhead, England: Open University Press.

Boniwell, I., \& Ryan, L. (2012). Personal well-being lessons for secondary schools: Positive psychology in action for 11-14 year olds. Maidenhead, England: Open University Press.

Brunwasser, S. M., Gillham, J. E., \& Kim, E. S. (2009). A meta-analytic review of the Penn Resiliency Program's effect on depressive symptoms. Journal of Consulting and Clinical Psychology, 77(6), 10421054. https://doi.org/10.1037/a0017671

Brunzell, T., Waters, L., Stokes, H., McLeigh, J. D., \& Spaulding, W. (2015). Teaching with strengths in trauma-affected students: A new approach to healing and growth in the classroom. American Journal of Orthopsychiatry, 85(1), 3-9. https://doi.org/10.1037/ort0000048

Brunzell, T., Stokes, H., \& Waters, L. (2016a). Trauma-informed positive education: Using positive psychology to strengthen vulnerable students. Contemporary School Psychology, 20(1), 63-83. https://doi.org/10.1007/s40688-015-0070-x

Brunzell, T., Stokes, H., \& Waters, L. (2016b). Trauma-informed flexible learning: classrooms that strengthen regulatory abilities. International Journal of Child, Youth and Family Studies, 7(2), 218-239. https://doi.org/10.18357/ijcyfs72201615719

Brunzell, T., Stokes, H., \& Waters, L. (2018). Why do you work with struggling students? Teacher perceptions of meaningful work in trauma-impacted classrooms. Australian Journal of Teacher Education, 43(2), 116-142. https://doi.org/10.14221/ajte.2018v43n2.7

Carr, D., Arthur, J., \& Kristjánsson, K. (2017). Varieties of virtue ethics: Introduction. Varieties of Virtue Ethics, 1. https://doi.org/10.1057/978-1-137-59177-7 1

Center for Education Innovation. (2015). Happy classrooms. https://www.educationinnovations.org/program/happy-classrooms

Charry, E. T., \& Kosits, R. D. (2017). Christian theology and positive psychology: An exchange of gifts. Journal of Positive Psychology, 12(5), 468-479. https://doi.org/10.1080/17439760.2016.1228010

Ciarrochi, J., Atkins, P. W. B., Hayes, L. L., Sahdra, B. K., \& Parker, P. (2016). Contextual positive psychology: Policy recommendations for implementing positive psychology into schools. Frontiers in Psychology, 7, 15-61. https://doi.org/10.3389/fpsyg.2016.01561

Cook, P. J., Dodge, K. A., Gifford, E. J., \& Schulting, A. B. (2017). A new program to prevent primary school absenteeism: Results of a pilot study in five schools. Children $\mathcal{E}$ Youth Services Review, 82, 262270. https://doi.org/10.1016/j.childyouth.2017.09.017

Creswall, J. D. (2017). Mindfulness interventions. Annual Review of Psychology, 68, 491-516. https://doi.org/10.1146/annurev-psych-042716-051139

Crouch, R., Keys, C. B., \& McMahon, S. D. (2014). Student-teacher relationships matter for school inclusion: School belonging, disability, and school transitions. Journal of Prevention $\mathcal{E}$ Intervention in the Community, 42, 20-30 https://doi.org/10.1080/10852352.2014.855054

David, S. A., Boniwell, I., \& Ayers, A. C. (2013). The Oxford handbook of happiness. Oxford, England: Oxford University Press.

Deci, E. L., \& Ryan, R. M. (2008). 'Facilitating optimal motivation and psychological wellbeing across life's domains': Correction to Deci and Ryan (2008). Canadian Psychology/Psychologie Canadienne, 49(3), 262. https://doi.org/10.1037/0708-5591.49.3.262

Degney, J., Hopkins, B., Hosie, A., Lim, S., Verma Rajendren., A., \& Vogl, G. (2012). Counting the cost The impact of young men's mental health on the Australian economy. https://about.au.reachout.com/wpcontent/uploads/2015/01/ReachOut.com-Counting-the-Cost-The-Impact-of-Young-Mens-MentalHealth-on-the-Australian-Economy-2012.pdf

Department of Health, Australian Government. (2018). Kids Matter. https://www.kidsmatter.edu.au/

Donaldson, S. I., Dollwet, M., \& Rao, M. A. (2015). Happiness, excellence, and optimal human functioning revisited: Examining the peer-reviewed literature linked to positive psychology. The Journal of Positive Psychology, 10(3), 185-195. https://doi.org/10.1080/17439760.2014.943801 
Durlak, J. A., Weissberg, R. P., Dymnicki, A. B., Taylor, R. D. \& Schellinger, K. B. (2011). The impact of enhancing students' social and emotional learning: A meta-analysis of school-based universal interventions. Child Development, 82(1), 405-432. https://doi.org/10.1111/j.1467-8624.2010.01564.x

Elmore, R. (1996). Getting to scale with good educational practice. Harvard Educational Review, 66(1), 1-27. https://doi.org/10.17763/haer.66.1.g73266758j348t33

Finkel, E. J., Simpson, J. A., \& Eastwick, P. W. (2017). The psychology of close relationships: Fourteen core principles. Annual Review of Psychology, 68, 383-411. https://doi.org/10.1146/annurev-psych$\underline{010416-044038}$

Foundation for Young Australians. (2017). The new work mindset: 7 new job clusters to help young people navigate the new work order. https://www.fya.org.au/wp-content/uploads/2016/11/The-New-WorkMindset.pdf

Foundation for Young Australians. (2017). The new work smarts: Thriving in the new work order. https://www.fya.org.au/wp-content/uploads/2017/07/FYA TheNewWorkSmarts July2017.pdf

Furlong, M. J., Gilman, R., \& Huebner, E. S. (Eds.). (2014). Handbook of positive psychology in schools. New York, NY: Routledge.

Hanover Research. (2011). A crosswalk of 21 st century skills. https://www.montgomeryschoolsmd.org/uploadedFiles/about/strategicplan/21stCenturySkills.pdf

Hattie, J. (2009). Visible learning: A synthesis of meta-analyses relating to achievement. London, England: Routledge.

Hattie, J. (2016, October). Shifting away from distractions to improve Australia's schools: Time for a reboot. Australian College of Educational Leadership Monograph (No 54).

Hayes, A., Weston, R., Qu, L., \& Gray, M. (2010). Families then and now: 1980-2010 (facts sheet). Melbourne, Australia: Australian Institute of Family Studies.

Helliwell, J. F., \& Aknin, L. B. (2018). Expanding the social science of happiness. Nature: Human Behaviour, 2(4), 248-252. https://doi.org/10.1038/s41562-018-0308-5

Hutchinson, S. (2017, January 9). Elite private schools spend millions on 'wellness' centres. The Australian. https://www.theaustralian.com.au/national-affairs/education/elite-private-schoolsspend-millions-on-wellness-centres/news-story/080cd5bc4ea0c416b0887ceabcb0b444

Hviid, P., \& Villadsen, J. W. (2014). Cultural identities and their relevance to school practice. Culture and Psychology, 20(1), 59-69. https://doi.org/10.1177/1354067X13515938

Kenway, J. (2013). Challenging inequality in Australian schools: Gonski and beyond. Discourse: Studies in the Cultural Politics of Education, 34, 286-308. https://doi.org/10.1080/01596306.2013.770254

Kern, M. L., Park, N., Peterson, C., \& Romer, D. (2017). The positive perspective on youth development. In D. Romer \& the Commission Chairs of the Adolescent Mental Health Initiative of the Annenberg Public Policy Center and the Sunnylands Trust (Eds.), Treating and preventing adolescent mental disorders: What we know and what we don't know (Vol. 2) (pp. 543-567). New York, NY: Oxford University Press.

Kern, M. L., Siokou, C., Spong, C., \& Oades, L. G. (2017). Positive systems science. Unpublished manuscript.

Kern, M. L., Waters, L. E., Adler, A., \& White, M. A. (2014). A multidimensional approach to measuring wellbeing in students: Application of the PERMA framework. Journal of Positive Psychology, 10(3), 262-271. https://doi.org/10.1080/17439760.2014.936962

Kern, M. L., Waters, L., White, M., \& Adler, A. (2014). Assessing employee wellbeing in schools using a multifaceted approach: Associations with physical health, life satisfaction, and professional thriving. Psychology, 5, 500-513. https://doi.org/10.4236/psych.2014.56060

Kern, M., Waters, L., Adler, A., \& White, M. A. (2015). Measuring whole school wellbeing in students and staff. In M. White \& S. Murray (Eds.) Evidence-based approaches to positive education in schools: Implementing a strategic framework for wellbeing in schools (pp. 65-91). Dordrecht, the Netherlands: Springer.

Kessler, R. C., \& Bromet, E. J. (2013). The epidemiology of depression across cultures. Annual Review of Public Health, 34, 119-138. https://doi.org/10.1146/annurev-publhealth-031912-114409 
Keyes, C. (2014). The nature and importance of positive mental health in America's adolescents. In M. J. Furlong, R. Gilman, \& S. Huebner (Eds.), Handbook of positive psychology in schools (pp. 9-23). Florence, Italy: Taylor \& Francis Group.

Kristjánsson, K. (2012). Positive psychology and positive education: Old wine in new bottles? Educational Psychologist, 47(2), 86-105. https://doi.org/10.1080/00461520.2011.610678

Kristjánsson, K. (2013). Virtues and vices in positive psychology: A philosophical critique. Cambridge, England: Cambridge University Press.

Kristjánsson, K. (2015). Aristotelian character education. London, England: Routledge.

McCall, T. D., Waters, L. E., \& White, M. A. (2015). A comparison between theological Christian approaches to wisdom and Peterson and Seligman's classification of character strengths and virtues. In M. White \& S. Murray (Eds.), Evidence-based approaches in positive education: Implementing a strategic framework for well-being in schools (pp. 27-41). Dordrecht, the Netherlands: Springer.

McCallum, F. \& Price, D. (2010). Well teachers, well students. Journal of Student Wellbeing, 4(1), $19-34$. https://doi.org/10.21913/ISW.v4i1.599

McCallum, F., \& Price, D. (2012). Keeping teacher wellbeing on the agenda. Professional Educator, 11(2), 47.

McCallum, F., \& Price, D. (2015). Nurturing wellbeing development in education: From little things, big things grow. Abington, England: Taylor and Francis.

McCallum, F., \& Price, D. (2017). Teacher wellbeing: A review of the literature. Sydney, Australia: The Association of Independent Schools of NSW.

McClelland, J. L. (1987). The case for interactions in language processing. In M. Coltheart (Ed.), Attention and performance XII: The psychology of reading (pp. 3-36). Hillsdale, NJ: Lawrence Erlbaum Associates.

McGrath, H., \& Noble, T. (2011). Bounce back!: A wellbeing and resilience program. Melbourne, Australia: Pearson.

Noble, T., \& McGrath, H. (2015). PROSPER: A new framework for positive education. Psychology of WellBeing: Theory, Research and Practice, 5(2), 1-17. https://doi.org/10.1186/s13612-015-0030-2

Noble, T., Wyatt, T., McGrath, H., Roffey, S., \& Rowling, L. (2008). Scoping study into approaches to student wellbeing: Final report. https://docs.education.gov.au/documents/scoping-studyapproaches-student-wellbeing-final-report

Oyserman, D. (2017). Culture three ways: Culture and subcultures within countries. Annual Review of Psychology, 68, 435-463. https://doi.org/10.1146/annurev-psych-122414-033617

Price, D., \& McCallum, F. (2015). Ecological influences on teachers' wellbeing and 'fitness'. Asia Pacific Journal of Teacher Education, 43(3), 195-209. https://doi.org/10.1080/1359866X.2014.932329

Quinn, S., \& Oldmeadow, J. A. (2013). Is the igeneration a 'we' generation? Social networking use among 9- to 13-year-olds and belonging. British Journal of Developmental Psychology, 31(1), 136-142. https://doi.org/10.1111/bjdp.12007

Roffey, S. (Ed.). (2012). Positive relationships: Evidence based practice across the world. Dordrecht, the Netherlands: Springer.

Roffey, S. (2016). Building a case for whole-child, whole-school wellbeing in challenging contexts. Educational \& Child Psychology, 33(2), 30-42.

Rusk, R. D., \& Waters, L. E. (2013). Tracing the size, reach, impact, and breadth of positive psychology. Journal of Positive Psychology, 8(3), 207-221. https://doi.org/10.1080/17439760.2013.777766

Rusk, R. D., \& Waters, L. (2015). A psycho-social system approach to wellbeing: Empirically deriving the five domains of positive functioning. The Journal of Positive Psychology, 10(2), 141-152. https://doi.org/10.1080/17439760.2014.920409

Seligman, M. E. P. (2011). Flourish: A visionary new understanding of happiness and wellbeing. New York, NY: Free Press.

Seligman, M. E. P., \& Csikszentmihalyi, M. (2000). Positive psychology: An introduction. American Psychologist, 55(1), 5-14. https://doi.org/10.1037/0003-066X.55.1.5

Seligman, M. E. P., Ernst, R. M., Gillham, J., Reivich, K., \& Linkins, M. (2009). Positive education: Positive psychology and classroom interventions. Oxford Review of Education, 35(3), 293-311. https://doi.org/10.1080/03054980902934563 
Slade, T., Johnston, A., Oakley Browne, M. A., Andrews, G., \& Whiteford, H. (2009). 2007 national survey of mental health and wellbeing: Methods and key findings. The Australian and New Zealand Journal of Psychiatry, 43(7), 594-605. https://doi.org/10.1080/00048670902970882

Slemp, G. R., Chin, T. C., Kern, M. L., Siokou, C., Loton, D., Oades, L. G. . . \& Waters, L. (2017). Positive education in Australia: Practice, measurement, and future directions. In E. Fryenberg, A. J. Martin, \& R. J. Collie (Eds.), Social and emotional learning in Australia and the Asia Pacific (pp. 101-122). Singapore: Springer.

St. Peter's College. (2015). Our preferred future: The strategic plan for St. Peter's College, Adelaide, 2015-2018. https://www.stpeters.sa.edu.au/wpcontent/uploads/2017/10/Strategic Plan Our Preferred Future.pdf

Suissa, J. (2008). Lessons from a new science? On teaching happiness in schools. Journal of Philosophy of Education, 42(3-4), 575-590. https://doi.org/10.1111/j.1467-9752.2008.00642.x

Tay, L., Tan, K., Diener, E., \& Gonzalez, E. (2012). Social relations, health behaviors, and health outcomes: A survey and synthesis. Applied Psychology: Health and Wellbeing, 5(1), 28-78. https://doi.org/10.1111/aphw.12000

Taylor S. E. (2011). Social support: A review. In H. S. Friedman (Ed.), Oxford handbook of health psychology (pp. 189-214). New York, NY: Oxford University Press.

Vallerand, R. J. (1997). Toward a hierarchical model of intrinsic and extrinsic motivation. Advances in Experimental Social Psychology, 29, 271-360. https://doi.org/10.1016/S0065-2601(08)60019-2

Wang, M., \& Eccles, J. S. (2012). Social support matters: Longitudinal effects of social support on three dimensions of school engagement from middle to high school. Child Development, 83(3), 877-895. https://doi.org/10.1111/j.1467-8624.2012.01745.x

Waters, L. (2011). A review of school-based positive psychology interventions. The Australian Educational and Developmental Psychologist, 28(2), 75-90. https://doi.org/10.1375/aedp.28.2.75

Waters, L. (2015). Why positive education? TLN Journal, 22(3), 16 - 18.

Waters, L. (2017). Progressing positive education and creating visible wellbeing. In S. Donaldson \& M. Rao (Eds.). Scientific advances in positive psychology (pp. 229-256). Westport: Connecticut: Praeger.

Waters, L., Sun, J., Rusk., R., Cotton, A., \& Arch, A. (2017). Positive education, visible wellbeing and positive functioning in students. In A. Jarden, M. Slade, \& L. Oades (Eds.), Wellbeing, recovery and mental health (pp. 245-264). Cambridge, UK: Cambridge University Press.

Waters, L., \& White, M. (2015). Case study of a school wellbeing initiative: Using appreciative inquiry to support positive change. International Journal of Wellbeing, 5(1), 19-32. https://doi.org/10.5502/ijw.v5i1.2

Waters, L., White, M., Wang, L., \& Murray, S. (2015). Leading whole-school change. In M. White \& S. Murray (Eds.), Evidence-based approaches in positive education in schools: Implementing a strategic framework for well-being in schools (pp. 43-63). Dordrecht, the Netherlands: Springer. https://doi.org/10.1007/978-94-017-9667-5 3

Waters, L., White, M., \& Murray, S. (2012). Toward the creation of a positive institution: St. Peter's College, Adelaide, Australia. AI Practitioner, 14(2), 60-65.

Wrench, A., Hammond, C., McCallum, F., \& Price, D. (2012) Inspire to aspire: Raising aspirational outcomes through a student well-being curricular focus. International Journal of Inclusive Education, 17(9), 932-947. https://doi.org/10.1080/13603116.2012.718804

White, M. A. (2010). Positive education. In L. Bormans (Ed.), The world book of happiness (pp. 142-145). Tielt, Belgium: Lannoo.

White, M. A. (2013). Positive education at Geelong Grammar School. Oxford handbook of happiness. https://doi.org/10.1093/oxfordhb/9780199557257.013.0049

White, M. (2014). An evidence-based whole school strategy to positive education. In H. Street \& N. Porter (Eds.), Better than OK: Helping young people to flourish at school and beyond (pp.194-198). Perth, Australia: Fremantle Press.

White, M., \& Murray, A. S. (2015). Well-being as freedom: Future directions in well-being. In M. White \& S. Murray (Eds.), Evidence-based approaches in positive education: Implementing a strategic framework for well-being in schools (pp. 167-175). Dordrecht, the Netherlands: Springer. 
White, M. (2016). Why won't it stick? Positive psychology and positive education. Psychology of WellBeing: Theory, Research and Practice, 6(2), 1-16. https://doi.org/10.1186/s13612-016-0039-1

White, M. (2017). Impact of activity: Future direction of positive education. In M. White, G. Slemp, \& S. Murray, Future directions in wellbeing: Education, organizations and policy (pp. 27-33). Springer, the Netherlands.

White, M. \& Kern. M. L. (2017). Wellbeing: If you treasure it you will measure it. Independence Journal of the Association of Heads of Independent Schools of Australia, 42(2), 50-54.

White, M. A., \& Murray, A. S. (2015). Wellbeing as freedom: Future directions in wellbeing. In M. A. White \& A. S. Murray (Eds.), Evidence-based approaches in positive education: Implementing a strategic framework for well-being in schools (pp. 167-176). Dordrecht, the Netherlands: Springer.

White, M. A., \& Murray, A. S. (Eds.). (2015). Evidence-based approaches in positive education: Implementing a strategic framework for well-being in schools. Dordrecht, the Netherlands: Springer.

White, M. A., Slemp, G. R., Murray, A. S., \& Cooperrider, D. L. (2017). Future directions in well-being: Education, organizations and policy. Cham, Switzerland: Springer.

White, M. A., \& Waters, L. E. (2015a). A case study of 'The Good School:' Examples of the use of Peterson's strengths-based approach with students. Journal of Positive Psychology, 10(1), 69-76. https://doi.org/10.1080/17439760.2014.920408

White, M. A., \& Waters, L. E. (2015b). Strengths-based approaches in the classroom and staffroom. In M. A. White \& A. S. Murray (Eds.), Evidence-based approaches in positive education: Implementing a strategic framework for well-being in schools (pp. 111-134). Dordrecht, the Netherlands: Springer.

White, M. A., Vrodos, J., \& McNeil, T. (2015). Student leadership, wellbeing and service: Integrating appreciative inquiry, strengths and leadership. In M. A. White \& A. S. Murray (Eds.), Evidence-based approaches in positive education: Implementing a strategic framework for well-being in schools (pp. 151-166). Dordrecht, the Netherlands: Springer.

World Health Organization. (2001). Ministerial Round Tables $201154^{\text {th }}$ World Health Assembly. Mental Health: A call for action by world health ministers. Geneva, Switzerland: World Health Organization.

World Health Organization. (2017). Depression and other common mental disorders: Global health estimates. http://www.who.int/mental health/management/depression/prevalence global health estimates/en/

Zenner, C., Herrnleben-Kurz, S., \& Walach, H. (2014). Mindfulness-based interventions in schools: A systematic review and meta-analysis. Frontiers in Psychology, 5(603), 1-20.

https://doi.org/10.3389/fpsyg.2014.00603 